\title{
THE POTENTIAL AND CHALLENGE OF HALAL FOODS IN JAPAN
}

\section{Hiroko Kurosaki Yamaguchi}

\author{
Associate Professor, the University of Kitakyushu, Japan \\ E-mail: hyamaguchi@kitakyu-u.ac.jp
}

Citation: Yamaguchi, H. K., 2019. The Potential and Challenge of Halal Foods in Japan. J. Asian Rur. Stud. 3(1): 1-16

\begin{abstract}
In preparing for the Tokyo Olympic Games held in 2020, and in aiming to become a "Country Built on Tourism", many travel facilities in Japan have started to provide halal foods and amenity goods, items that are permissible or lawful in Islamic law, Muslim prayer rooms, etc. in order to accommodate Muslim tourists. Many Japanese companies and municipalities are also interested in exporting their products from the Islamic area, and obtaining the certification of halal from some Islamic organizations. The process for acquiring halal certification is becoming complicated and expensive, so that many of companies and municipalities have abandoned it. There are about 110,000 Muslims in Japan. It is sometimes difficult for them to find halal foods and other goods, and the need for such items is typically addressed by a small halal industry. There is a "dualism" or lack of communication and collaboration between those organizations that are oriented to Muslim tourists and exports, and the small halal industries stated above. The present study also points out that many Japanese people mistakenly assume that halal foods are exclusively for Muslims. Halal foods, however, have potential for meeting the needs of non-Muslim Japanese consumers who are looking for safe and trustworthy foods.
\end{abstract}

Keywords: Potential and challenge; Halal foods; Japan

\section{Introduction}

In preparing for the Tokyo Olympic Games, which will be held in 2020, and in aiming to become a "country built on tourism," many travel facilities in Japan have started to provide halal foods and amenity goods - items that are permissible, or lawful, in Islamic law, Muslim prayer rooms, and so on-in order to accommodate Muslim tourists, especially those from other Asian countries. These visitors are increasing in the economic growth. Not a few Japanese companies and municipalities are also interested in exporting their products to the Islamic world. These tourist facilities and organizations that aspire to export are eager to obtain halal certification from Islamic organizations, in hopes of confirming the halalness of their products and services.

In the societies of the Middle East, where Muslims make up an absolute majority of the population, all commodities are taken for granted as halal, so less attention has been paid to the halal certification system. Some previous studies have claimed that halal consciousness is sharpened in multi-cultural and multi-religious contexts where Muslims and non-Muslims coexist. In accordance with the constant flow of people, commodities, and information in the globalized world, the contact zone between Muslims and non-Muslims has been increasing. In Japan, where the Muslim population 
occupies only a small fraction of society, quite a few companies and municipalities are eager to obtain halal certification from Islamic organizations to confirm the halalness of their products and services. As the demand for halal certification has increased, several consulting agencies have been established, and certification is becoming both an intensifying business activity and a site of competition among various agencies, some of which are suspected unauthorized. As a result, the process for acquiring halal certification is becoming increasingly complicated and expensive, so that many of companies and municipalities have abandoned the effort and finally given up their hopes of widespread Muslim tourism in Japan (Yamaguchi, 2017). As of 2017, there are about 110,000 Muslims in Japan. It is sometimes difficult for them to find halal foods and other goods, especially in small cities, and the need for such items is typically addressed by a small halal industry that is often engaged via cooperative works between non-Muslim Japanese and Muslims (Yamaguchi, 2009).

Given the growth of the world's halal market, as the Muslim population increases, the trend towards halal certification in Japan is expected to continue for some time. This trend, however, has begun to show a number of problems, as outlined above. We should also note that Japan is at a crossroads; it must determine whether the present rising interest in halal will ends after a temporary boom, or whether the country can and will sustainably accept Muslims and live together with them.

Taking these issues into account, this study investigates the current situation and challenges regarding halal foods in Japan. Along with the macro background of the trend of halal certification in Southeast Asia and the Middle East, the paper examines, among other phenomena, the adverse effects of excessive commercialism in Japan by pointing out, for example, the "dualism" or lack of communication and collaboration among organizations who are oriented to Muslim tourists and exports, and those retailers who mainly target local Muslim consumers from the viewpoint of the peripheral areas of contact zones between Muslims and non-Muslims. The paper also considers the tendency of Japanese people's misunderstandings; they often take Islamic norms too strictly and overlook the diversity of each Muslim's religious practice. There are also many Japanese people who mistakenly assume that halal foods are exclusively for Muslims, and that non-Muslims are not allowed to consume them. Regarding these situations, this paper considers the potential of halal foods for meeting the needs of nonMuslim Japanese consumers who are looking for safe and trustworthy food.

In that international migration is becoming active via globalization, the contact zones where people from different social backgrounds encounter each other and coexist are expanding. In Japan, immigration policies and how we live with "cultural others" are urgent issues, as is the realization of the country's tourist-friendly nature, as promoted by the Japanese government. Furthermore, taking account the fact that it is not only Muslims, but almost all human societies, that have unique cultural norms and rules on food choices, this paper considers the case of halal food in Islam as one of the first steps for addressing and resolving such universal problems as international migration, understanding, and living with cultural others. 


\section{The Rising Interest in Halal Products}

\subsection{Muslim Population Dynamics in the World and Japan}

During the latter half of the 20th century, the proportion of the world's Muslim population increased from $13.6 \%$ to $20 \%$. More recently, it has climbed to $22 \%$, or about 1.6 billion people (Tanada, 2015). According to one survey, it is expected that the proportion of Muslims will grow more than twice as fast as the overall world population from 2015 to 2060 and, in the second half of the 21st century; Muslims will likely surpass Christians as the world's largest religious group (Pew Research Centre, 2017).

The intense exchange between Japanese and Muslim societies began in Japan in the late 19th century, from the end of Edo to the beginning of Meiji era. By 1900, there were Indian Muslim merchants dwelling in Kobe, a famous port city, and other areas in Japan. When Japan's international position rose as a result of its victory in the RussoJapanese War, the Muslims who had been under European rule became interested in Japan. In the 1920s, Tatar Muslims who left Russia after the Russian Revolution surged into Japan and began to settle, forming small Muslim communities and opening schools. At the same time, while the Japanese government extended its forces into Asia, research projects on Muslims as a national policy began. In the late 1930s, Japan's Muslim population reached 500-700 people, consisting of about 400-600 Tatars who had exiled from Russia, Indian Muslim merchants in Kobe, Japanese converted Muslims, and so on (Tanada, 2015).

Since many Tatars obtained Turkish citizenship and left Japan after the Second World War, the Muslim population in Japan decreased to only a few hundred people by the mid-1950s. Then, it began a gradual increase, to about 6,000 , by the mid-1980s. During the economic bubble period of the late 1980s, a large number of foreign laborers from West and South Asia migrated to Japan, increasing the Muslim population to more than 100,000, including illegal residents. After another decline, it increased once more, so that the current Muslim population is estimated to be roughly 110,000; 100,000 of these are non-Japanese, and about 10,000 are Japanese (Pew Research Centre, 2017).

\subsection{Increase of Muslim Tourists}

Interest in halal matters in Japan is rising, however, but this is not because of the recent increasing trend of Muslim residents in Japan; instead, it derives from two factors: a new focus on accommodating Muslim tourists and the growth of the world's halal marketplace. Now more than ever, Japan is home to halal businesses that target Muslim tourists. The number of tourists visiting Japan was between 4 and 5 million in the late 1990s. In aiming to become a "country built on tourism," the Japanese government launched its "Visit Japan Campaign" in 2003. In preparing for the Tokyo Olympic Games, which will be held in 2020, the government set a goal of attracting 20 million tourists per year. This was achieved in 2016. In promoting tourism, especially from Southeast Asia, the visa requirements for short-term residents, for example, have been relaxed. Along with increasing incomes among the middle class and the emergence of low-cost carriers now offering flights between Japan and other Asian countries, the number of tourists from Southeast Asia's regions with large Muslim populations, such as Indonesia, Malaysia, and Singapore, has increased since 2012. In light of these trends, the travel industry has moved, since roughly 2014, to improve the 
tourist facilities and services, in order to welcome Muslim tourists (The Japan Tourism Advisory Council, 2014). The momentum to welcome Muslims tourists is rising in Japan.

\section{Islamic Societies as Place of Origin for Halal Certification and Global Markets}

\subsection{Halal Certification Projects in Southeast Asia}

The global halal market is estimated to include 1.6 billion people, and to amount to \$2.1 trillion annually (Jetro, 2014). Another reason for the increasing interest in halal certification in Japan is rooted in the attractive nature of the world's speedily growing halal market.

Southeast Asian countries initiated halal certification projects before other areas of the world did, and each country now has bodies for inspection and certification (See Table 1). In Malaysia, for example, in response to the Islamic reconstruction movement of the 1970s and the government's "Islamization" policy implemented in 1980, a halal certification system began in 1982. Since the 1990s, the Malaysian government has promoted a Halal-Hub strategy as a national policy to take a leading role in the global halal business (Tomizawa, 2007). The Department of Islamic Development Malaysia (JAKIM) has conducted halal certification based on a standard called "MS1500: 2004," which was enacted by Department of Standards in Ministry of Science, Technology and Innovation in 2004 and has been renewed several times since. The case of Malaysia, where a government organization controls the certification project, is a worldpioneering example. Malaysia has also established several halal industrial complexes known as "halal parks," in the country, that specialize in producing and transporting halal products and which try to attract enterprises from overseas by virtue of tax incentives (Arata, 2018).

In Indonesia, a need emerged for an organization charged with scientifically confirming and certifying the halalness of foods emerged in 1988 after an incident when a large amount of lard was found in a rice field in the Eastern Java Province (Tomizawa, 2007). In response to this incident, the Indonesian Ulama Council (MUI) established a non-profit organization, the Institute for Assessment of Food, Drugs and Cosmetics of Indonesian Ulama Council (LPPOM-MUI), which engages in inspections of the halal nature of the products ingested in and used directly on the human body. In 2014, the halal product warranty law (National Law 2014 No. 33) was approved, and another halal inspection agency, the Institute for Halal Inspection (LPH), was established to come into force after the law becomes effective in 2019. Thereafter, the halal certificates will be issued under the Agency for Halal Product Guarantee (BPJPH), which will be established under the Ministry of Religious Affairs. The MUI and the BPJPH will cooperate to approve the inspectors, the inspection organization, and to judge the halal nature of the products (Arata, 2018). 
Published by Hasanuddin University and Asian Rural Sociology Association

Table 1. Main Halal Certification Bodies in Southeast Asia

\begin{tabular}{|c|l|c|c|}
\hline Country & \multicolumn{1}{|c|}{ Main Certification Body } & Established \\
\hline Malaysia & $\begin{array}{l}\text { Department of Islamic } \\
\text { Development Malaysia } \\
\text { (JAKIM) }\end{array}$ & $1980 \mathrm{~s}$ \\
\hline Indonesia & $\begin{array}{l}\text { Institute for Assessment of } \\
\text { Food, Drugs and Cosmetics of } \\
\text { Indonesian Ulama Council } \\
\text { (LPPOM-MUI) }\end{array}$ & $\begin{array}{l}\text { The Central Islamic Committee } \\
\text { of Thailand (CICOT) }\end{array}$ & 1989 \\
\hline Singapore & $\begin{array}{l}\text { Islamic Religious Council of } \\
\text { Singapore (MUIS) }\end{array}$ & $1972 \sim$ \\
\hline
\end{tabular}

Adapted from Tomizawa (2007) and Arata (2018)

In addition to these cases, most Southeast Asian countries have organizations that inspect and certify of halal goods, as shown in Table 1. Each certification body establishes its own standards by referring to the others' standards while balancing the circumstances of their own country and the opinions of experts.

\subsection{How to Obtain Halal Certification in Japan}

Consider an example of food produced in Japan for export to an Islamic area. The halal certification system will be referred to when confirming the halal nature of the products. There are two main ways to secure halal certification in Japan. One is to apply directly to the inspection/certification bodies approved by the export destination countries (See A in Figure 1) to obtain a certification from them. The other is to apply for and obtain certification from the bodies in Japan authorized by the certification bodies in the respective export destination countries (See B in Figure 1).

Today, there are several inspection and certification bodies in Japan (See B in Figure 1 and Table 2). They oversee the certification of a limited number of specific items, such as processed food, slaughtering, flavorings and so on, under the authorization of a particular overseas institution. Japanese companies and municipalities that attempt to obtain halal certification need to fulfill the criteria set by each certifying body, to pass their close inspection and renew their certification every year. Given that there is no world standard for halal certification to date, and instances where products that have been certified by an overseas body are not always accepted in other countries as halal, Japanese manufacturers should seek several certifications, in accordance with the 
requirements of each export destination country. There are many consulting agencies that mediate between domestic certification bodies and Japanese companies and municipalities. As those agencies often aim to monopolize the local market of halal products in regional areas and impose brokerage fees, it is becoming increasingly complicated and expensive for manufacturers to obtain certifications and establish sales channels.

Figure 1. Halal Certification Process

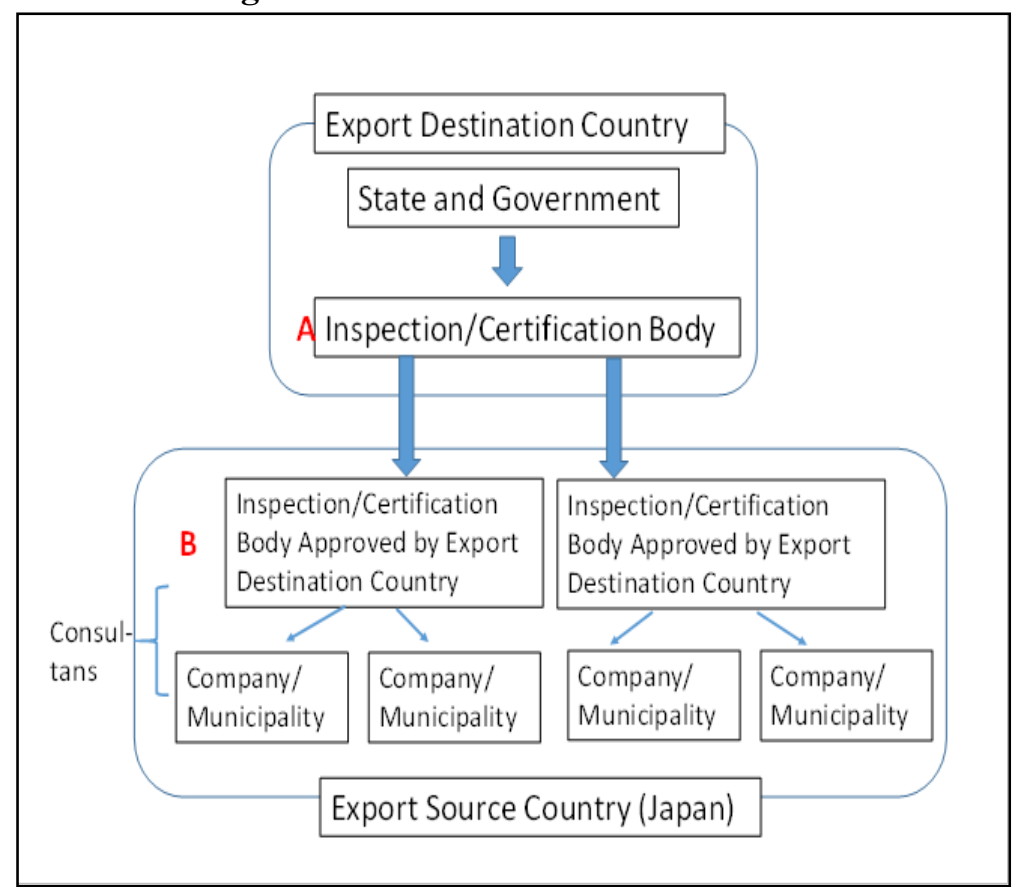

Adapted from Jetro ed., (2014).

Table 2. Main Certification Bodies in Japan

\begin{tabular}{|c|c|c|c|c|c|}
\hline Country/Regeon $\cdot$ Bod & Malaysia $\cdot \mathrm{JAKIM}$ & \multicolumn{3}{|c|}{ Indonesia $\cdot$ MUI } & $\mathrm{UAE} \cdot \mathrm{ESMA}$ \\
\hline $\begin{array}{l}\text { Japanese Certificating Body } \\
\text { (abbreviation) }\end{array}$ & & Slaughter & \begin{tabular}{|l} 
Food \\
Processing
\end{tabular} & Flavoring & \\
\hline Japan Muslim Association (JMA) & O & & O & O & \\
\hline Japan Halal Association (JHA) & 0 & & & & 0 \\
\hline $\begin{array}{l}\text { Japan Halal Unit Association } \\
\text { (JHUA) }\end{array}$ & O & & & & \\
\hline Japan Islamic Trust (JIT) & O & & & & O \\
\hline $\begin{array}{l}\text { Muslim Professional Japan } \\
\text { Associagtion (MPJA) }\end{array}$ & O & O & O & & \\
\hline $\begin{array}{l}\text { Nippon Asia Halal Association } \\
\text { NAHA) }\end{array}$ & O & & & & \\
\hline Emirates Halal Center (EHC) & & & & & 0 \\
\hline
\end{tabular}

Adopted from Arata (2018). 


\subsection{Intensifying Competition among Agencies and the Refinement of Standards}

Some of the features that have characterized recent trends in halal certification are the absence of international-unified standards and the tendency toward competition among the certification bodies. There have been several attempts to unify the world's certification bodies. The World Halal Food Council (WHFC), for example, was established in 1999 with a secretariat located in Indonesia. Then, the World Halal Council, which split from the WHFC formed. Some organizations have repeatedly broken up and changed their names (Arata, 2018). To date, no comprehensive agency has been established, nor have worldwide halal standard or logo been agreed upon.

Recently, countries in the Middle East, the birthplace of Islam, have entered the certification project, albeit later than the bodies in Southeast Asia mentioned above. In the Middle East, there are several standards, such as UAE Standard, led by the UAE; the Gulf Standard, led by Gulf Cooperation Council; the OIC-SMIIC Standard, by Organization of Islamic Cooperation, and so on. Each of these defines standards and guidelines not only for certifying products and services, but also for certifying the certification bodies themselves. Among them, the OIC-SMIIC established a comprehensive guideline in 2011 and attempted to make it known via the worldwide halal events held in 2014 and 2015. Though it seems that the guidelines are being recognized gradually, they have not yet become a worldwide, common framework (Arata, 2018). As can be understood in light of the above-mentioned situation, it remains very difficult to formulate an international unified standard for halal certification.

Another significant feature of the recent trends in halal certification is that as the science and technology developed, inspection standards and criteria are becoming more refined and the certification processes are growing more complicated. Let us take a case of one incident arose over a product by a major Japanese seasoning company, which will we refer to here as Firm A. Firm A's seasoning had long been popular in Indonesian kitchens, and it had obtained halal certification from LPPOM-MUI, but was judged as haram (illegitimate or prohibited) by the MUI in 2000. At one time, Firm A had used a cattle-derived medium to promote fermentation during the manufacturing process. It later switched to a medium derived from plants made in the US. During the manufacturing process of the medium, the firm in US used a pig-derived enzyme as a catalyst. After the president of Indonesia at the time, Abdurrahman Wahid, intervened to defend that the product itself was not haram, and Firm A was responding sincerely with the replacement of pig-derived enzymes with other substances, the situation was settled and the firm reclaimed the public's trust.

One element that led to the above-mentioned incident has been the refinement of halal certification standards and processes, due to the development of science and technology and dissemination of that knowledge. In the case of Firm A's seasoning in Indonesia, no pig ingredients were actually contained in the medium or in the product. As briefly demonstrated above, today, the appropriateness of an item's halal nature can be questioned at the micro and Nano levels, not only in their final product form, but also in terms of the materials and mediating substances with which they come into contact and their logistics and consumption.

Those involved in the halal industry are a diverse group both ethnically and religiously. This has to do with the absence of unified world- standards and the 
refinement of certification standards. In brief, non-Muslim traders who intend to enter the halal industry tend to prefer a more refined and highly applicable certificate and certification system. This tendency encourages further the elaboration and refinement of the certification system and leads to competition among certifying bodies over their authority in the certification projects. Namely, a cyclical situation emerges in which the more developed and clarified the certification systems are, the more non-Muslims will be attracted to the halal industry, so that more sophisticated certification systems will be needed.

\section{A Decade in a Region with Few Muslim Residents}

\subsection{The Halal Industry in Japan and Okayama Prefecture}

In the late 1990s, there were more than 100 shops and wholesalers dealing with halal foods in Japan. Most of them were managed by Muslims from South and West Asian countries, whose populations increased dramatically during the bubble economy period of the 1980s, as mentioned above. Most of these shops were located in Tokyo and other industrial cities, in the Northern Kanto area, the Tokai area, and so on, where large number of foreign workers lived. The customers of these halal shops were usually limited to Muslims, and it was typically difficult for shop owners to expand their base beyond the small Japanese Muslim community. As a result, these shops often faced excessive competition (Higuchi, and Tanno, 2000), and it made it difficult for shopkeepers to maintain their stores' sustainability (Yamaguchi, 2009).

In that there were few halal shops in Japan's smaller cities, Muslims living there would face difficulty in getting halal foods, and they unavoidably had to substitute ordinary foods that were free from alcohol and pig ingredients for halal foods until the beginning of the 2000s. Some of this study's author's Muslim friends referred to a food ingredients list that had been uploaded to the website of a mosque in Nagoya City, or asked food manufacturers direct questions, via their customer service lines, about food ingredients, in order to avoid the consumption of haram ingredients. One of the features in the cities with fewer Muslims was the emergence of micro halal businesses run by both Muslim and non-Muslim store owners; this will be considered later.

\subsection{Overview of Foreign Residents in Japan}

According to statistics from the Immigration Bureau of Ministry of Justice, the total number of foreigners living in Japan at the end of 2015 was 2,232,189 people, or $1.7 \%$ of the total population. In terms of country and region of origin, China is the largest $(30 \%)$, followed by Korea (22\%), the Philippines (10\%), Brazil (8\%) and others (See Figure 2). 
Figure 2. Percentage of Foreigners by Country/ Region of Origin (2015)

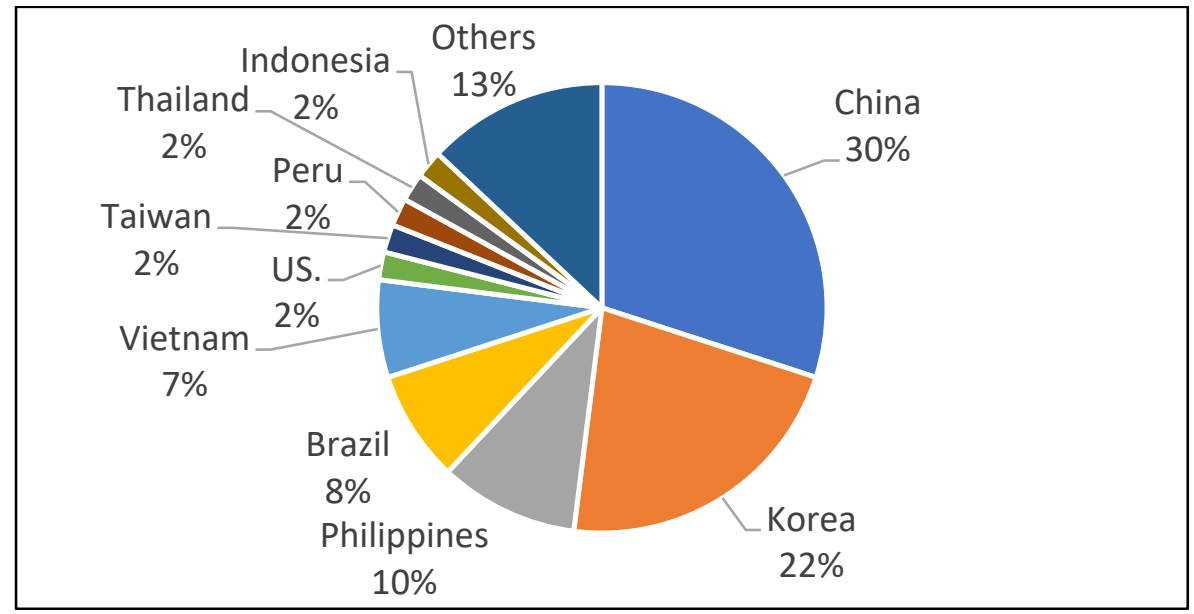

See the Immigration Bureau of Japan's website [12]

In the Okayama Prefecture, which is located at the western part of Honshu Island, textiles and heavy industry are the major employment industries. The population is concentrated in the coastal-industrial area of the Seto Inland Sea. In many other municipalities, particularly in the northern part of the prefecture, depopulation and aging are worsening problems. The population of the Okayama Prefecture was about 1,913 million in 2015. It has been on a downward trend since peaking at 1.957 million in 2005 (Okayama Prefecture official, 2018). Foreign residents in the Okayama Prefecture accounted for 22,439 people at the end of 2015 (approximately 1\% of the total number of foreign nationals residing in Japan, ranked 28th among 47 prefectures) and have been on an upward trend since 2014 (Okayama Prefecture official, 2018). In terms of nationality, the Chinese and Koreans are dominant, and the Vietnamese and Filipino populations are relatively large. Many of the latter two groups work as technical intern trainees to fill the labor shortage in the Japanese manufacturing and construction industries.

According to Tanada Calculation Method, which multiplies the Muslim population ratio of the country of origin to the population of the foreign residents by the nationality in a certain prefecture, the Muslim population in Okayama was estimated about 670 people in 2006 and 870 people as of 2012 (about $0.8 \%$ of Muslims in Japan). Thereafter, even the Muslim population is inferred to be on an upward tendency. In recent years, we can presume there are no more than 1,000 people in the area, including Japanese Muslims who are spouses of Muslims and converts to Islam.

\subsection{Micro Halal Businesses: Handmade Halal Meat Production and Sales}

As is the case of Okayama Prefecture, in areas with smaller Muslim populations, there have been no halal food shops run by foreign Muslims. We can observe this by considering the relatively large number of Muslims residing in areas in the 1990s, and how, in areas with fewer Muslims, the halal food industry is often engaged in some sort of cooperative featuring Muslims and non-Muslims. An example in Okayama Prefecture is Mr. K, a non-Muslim Japanese man who runs a poultry farm in the suburbs (See Figure 3). 
Mr. K has long loved traveling throughout Southeast Asia, and he led exchange events at the international exchange center with foreign students from Southeast Asia who was studying at universities in Okayama city. In the mid-1990s, after hearing that many Muslim students from abroad had difficulty finding Halal foods, Mr. K began to sell halal food to those students once a week at the entrance to their dormitory. He purchased halal foods from a Japanese friend, Mr. N (a non-Muslim) who runs a wholesaler of imported halal foods, such as instant noodles, seasonings, and so on in Gifu Prefecture.

In the early 2000s, Mr. K began to manufacture halal beef with the help of Mr. E., as a former international student from Indonesia who, after graduating, ran a halal shop in Fukuoka Prefecture. He had been purchasing imported halal foods from Mr. N. Mr. N introduced Mr. E to Mr. K, and they soon realized the need to produce halal meat. Mr. $\mathrm{K}$ purchased some cattle from a contract meat supplier and brought Mr. E to Okayama once each month from Fukuoka to slaughter the stock in an Islamic way. Mr. K used his connections to get Mr. E into the slaughterhouse and, after reciting of the appropriate Islamic prayers (Bismillahi rahmanir rahiem: In the name of Allah) Mr. E slaughtered the cows. Then, the non-Muslim staff at the slaughterhouse processed the skin and internal organs. After that, $\mathrm{Mr} . \mathrm{K}$ and $\mathrm{Mr}$. E divided the carcass into right and left halved and processed the meat for packing at the slaughterhouse. This commercial meat was divided between Mr. K and Mr. E in proportion to their respective needs, frozen, and sold (Yamaguchi, 2009).

Figure 3. Micro Halal Network in an Area with a Small Muslim Population

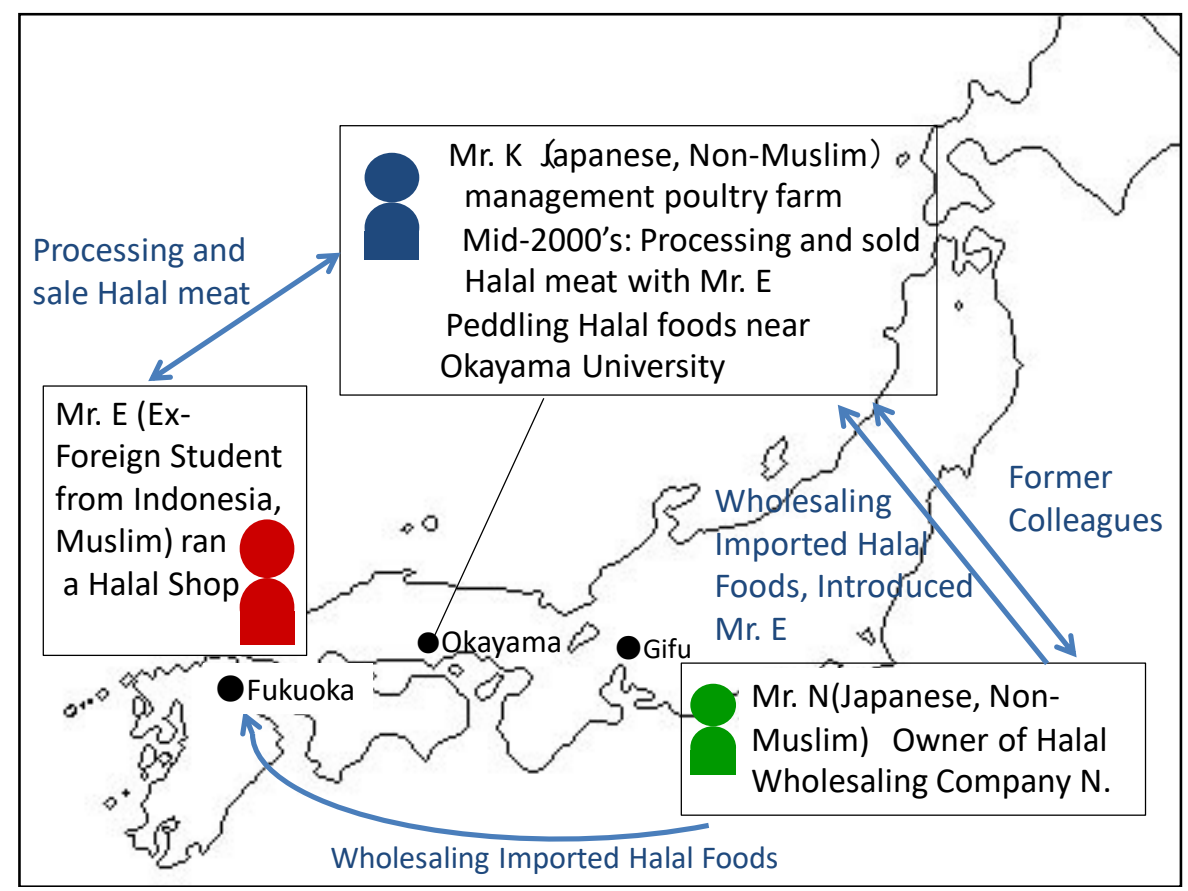

In addition to Mr. K's sale of this "hand-made halal beef" and other imported halal foods purchased from Mr. N, Mr. K also wholesaled commodities to an Indonesian restaurant owned by a Japanese woman in Okayama City and to the Kansai airport for in-flight meals until 2005-2006. After that, Mr. K stopped producing halal meat, due to 
restrictions on slaughterhouse entry and the increasing rate of inexpensive imported halal meat entering the Japanese market. He refocused on selling just imported halal products. His sales, along with those commodities stated above, included fresh eggs from Mr. K's poultry farm and side dishes such as halal chicken cutlets made by Mr. K. These are less expensive and are popular among Muslims and non-Muslim foreign students. According to an interview I conducted, it seems that most of the Muslim students who bought these items knew that those commodities, such as side dishes and halal meat produced by Mr. K, were not authorized as halal by any certifying body, and accordingly no halal mark was sealed on those handmade commodities. An Indonesian Muslim student who was shopping said, "There is no doubt that the meat Mr. K sells is halal. What is important is that Muslims slaughtered [it] in the name of Allah."

Mr. K's shop also provides a place for interaction among international students. Mr. $\mathrm{K}$ himself is familiar with many of the foreign students who shop with him frequently, and there are several students who have kept in close contact with him even after their graduation. One student from Malaysia, for example, came to the shop deliver an invitation to his upcoming wedding, which would be held in Malaysia. As these vignettes demonstrate, what is important in a micro halal business is trust among producers, sellers, and consumers; whether the products had a halal certification and mark or not is a secondary matter for these Muslim consumers.

As demonstrated above, Mr. K's shop is popular among foreign students, and his wares are considered indispensable for the lives of Muslim and non-Muslim students alike. Mr. K has complained about the "booming" trend of halal certification among local companies and municipalities in recent years, and said, "It is important to understand the preferences of Muslims. It is not all products in Japan [that] can be suitable to the taste of Muslim consumers, even if [they have] halal certification and mark." At the same time, Mr. K was also dissatisfied with his sales that have not extended beyond the scope of a side business, as far as sales are concerned. He had hoped to develop his halal business and planned to cultivate coriander, lemon grass, and other herbs in Japan for export to South and Southeast Asia. Observing the recent economic growth in many Asian countries, he was very motivated, saying, "The business chance is in the best in the two decades since I've started selling."

The halal business in areas dominated by non-Muslim residents, like Okayama, have no central source for the supply of halal foods, and the halal business is managed by a network of only a few people, including both Muslims and non-Muslims who are connected by a thin thread. The situation cannot be seen as a simple dichotomy between companies that only pursue profit versus private salespeople with good intentions and do not care about profit. Instead, micro halal businesses in areas with few Muslims are relatively unstable and not fully sustainable.

\subsection{Recent Trends: The "Boom" of Halal Certification Acquisition}

In Okayama Prefecture, the trend of non-Muslim enterprises and municipalities entering the Muslim inbound tourism and export business has been remarkable since the early 2010s. Two cases are considered briefly below. 


\subsubsection{A Confectionery Company Expecting inbound and Outbound Demands}

A limited company, Y, located near Okayama City, has produced rice crackers for about 50 years. In December 2013, Company Y acquired halal certification from the Nippon Asia Halal Association (NAHA, see Table 2), relative to its special seasoned rice crackers with unglazed soy sauce. According to the firm's president, Mr. Y, he decided to pursue halal certification in anticipation of rising demand for the products as souvenirs among Muslim tourists and Japanese businesspersons travelling in the Middle East. By obtaining halal certification, he aimed to fulfill the criteria required by the NAHA, and he saw this as a good opportunity to review the safety and cleanliness of the company's materials and manufacturing processes. In the future, he wants to accept mail orders from overseas, to introduce Japanese food culture to other parts of the globe.

Mr. Y also pointed out that the absence of a unified international standard of certification makes the export process complicated and expensive. Regarding domestic sales, because several consultant agencies are competing to dominate the markets and sales channels of halal foods in the area, it is very hard for small companies like Y to get enter the market without contracting with consultants that charge an intermediate margin. Mr. Y, without making a contract with any consultant, has barely been able to continue selling his products at the souvenir stores in the main train station and Okayama Airport, where he had long been a wholesaler of common non-halal goods before obtaining halal certification. In many cases, however, the profit associated with obtaining halal certification is not guaranteed, and the sales of newer halal companies are in decline. Some of his competitors in other prefectures, for example, have given up on the manufacture of halal products and returned their certification. In short, it can be difficult for newer enterprises to enter the market and operate a halal business sustainably, given that halal certification is becoming increasingly complicated and competitive among related organizations.

\subsubsection{Regional Revitalization Project and Halal Business}

There are some distinctive examples of halal businesses undertaken by diverse actors. The case of a bakery is presented here. In March 2015, Halal Bakery L opened in central Tokyo. The headquarters, O-factory, which is located in Okayama City, had directly managed a bakery that sold bread made of halal rice flour produced in a town named $\mathrm{KC}$, which is famous for rice production in Okayama Prefecture. KC's local government acquired halal certification for its rice flour under by consulting with Consultant A, located in Okayama City. According to A's press release, the Halal bakery was opened in cooperation with the $\mathrm{KC}$ town, for the purpose of revitalizing local agriculture, the consumption of rice, job creation, and so on. This is an example of the new form of cooperation between regional revitalizing projects and halal businesses in a local area. A non-Muslim housewife who used the bakery said on her weblog that, since the materials used in the bread is safe and trustworthy, anyone, even those with food allergies, may consume without anxiety.

Turning back to the Bakery L in Tokyo, in addition to the bread made from halal rice flour, other halal breads and sweets were offered. The bakery gained secured its halal certification from the Islamic Culture Centre of Tokyo (JIT, in Table 2), which plied to all of the store's facilities and products. 
In February 2016, I visited Bakery L. The store was located in a well-heeled area of central Tokyo. It was small and cozy shop, featuring a wide array of breads and proceeded foods, such as jam and cream. The prices were almost the same as those for ordinary commodities from the O-factory. Schoolgirls from a neighboring high school and young housewives filled the bakery. In the kitchen, a young Muslim woman, originally from Syria, who was studying at a university in Tokyo and worked part-time at the bakery as a bread-maker. According to Mr. KK, the non-Muslim Japanese manager of the bakery, the Syrian woman answers questions when Muslim customers ask about their products. Mr. KK also said that Muslims account for about $30 \%$ of the bakery's customers; most of them are officials from nearby embassies and Muslim students from a neighboring university. The remaining $70 \%$ of customers are nonMuslim residents and students in the vicinity. Because of the bread sold at Bakery L is made using natural materials and manufacturing methods, it is also popular and preferred by young housewives with small children.

When the author visited the bakery about four months after the first visit, the wording "Halal Bakery" had been deleted from the shop's name and it had been changed to a more common name. The halal certificate had also been removed from the wall, and the Syrian Muslim employee had quit. According to the shop manager, Mr. $\mathrm{KK}$, in response to increasing orders from non-Muslim Japanese consumers for cooked bread using pork, and taking into account the cost of annual halal certification, the bakery ceased its pursuit of halal certification and accordingly changed the shop's name. The bakery divided part of the kitchen into a zone that continued to follow the halal methods for making bread, while the rest of the kitchen did not. Instead of holding halal certification, the bakery presented new information to customers explaining the new manufacturing methods and ingredients, and noting that some items might contain alcohol or pork. As for the influence of the withdrawal of the bakery's halal certification, it seems that the number of Muslim consumers who follow the halal certification has decreased, but some Muslim customers continued to come to the bakery, regardless of its certification status. They feel that they understand and trust the materials and manufacturing methods of the bakery. These customers are mainly from Southeast Asia and, in accordance with the renewal of the menu mentioned above; the number of non-Muslim Japanese customers has increased. Mr. KK reports that, overall, sales have risen.

The case of the bakery seems to exemplify a Japanese company attempting to provide products to Muslim consumers without certification by clarifying the ingredients and processes used and then leaving the choice of whether to buy or not to Muslim consumers themselves. However, not so long after my last visit to the shop, the bakery closed. The reason for its closing is not clear, but given that it was not open for long, it seems likely that it proved too difficult to manage a halal specialty shop, even in a large city like Tokyo.

\section{Conclusion: Toward Halal Foods Opened to Everyone}

The present paper has examined the rising interest in halal foods and the boom of halal certification in Japan in recent years. In particular, it has discussed the rapid development of the halal industry over the last decade in areas with few Muslim 
residents, referring to the case of the Okayama Prefecture. In European society, where a majority of the population is not Muslim, more than $90 \%$ of those employed in the halal industry are non-Muslims. The situation of Muslims consuming halal foods produced by non-Muslims has come to be commonplace in the global halal industry (Tomizawa, 2007). As for the background of the boom in halal certification in Japan, we can note that the number of Muslim tourists visiting Japan is increasing, and the world's Muslim markets are growing. This has led to the further expansion of contact zones between Islamic spheres and non-Islamic spheres.

In Japan today, topics related to halal status are frequently taken up in the media, and in the last decade the word halal itself has become known among non-Muslim Japanese people. It is desirable that common Japanese people, who usually live lives unrelated to a certain religion, and especially to Islam, can accept the fact that there are people who have different faiths and different lifestyles as a matter of course. However, the moves by companies and municipalities who are attempting to respond to Muslims' demands in the recent years are often too concentrated on obtaining halal certification. This business-based tendency is developing rapidly, and those involved often overlook the fundamental importance of understanding others' cultures. Several issues, such as those outlined below, have been observed through the consideration of the present study.

First, in Japanese industry, the halal certification tends to be seen as a universal passport for launching a halal business, a market worth about $\$ 2.1$ trillion, or 200 trillion Japanese yen, worldwide. There is, however, no uniform, international standard of halal, and the acquisition and renewal of halal certification requires the strict management of materials and production lines. In short, it costs a great deal to fulfill each criterion for halal certification. Furthermore, the competition among the agencies concerned with the domination of the relatively small halal market in Japan makes it hard for companies and municipalities to promote halal commodities without contracting with consultants. As a result, the process for obtaining halal certification is growing more complicated and expensive, and not a few companies have failed to realize their expected profits. Accordingly, they have given up on acquiring or renewing the certification, or completely abandoned efforts to accept or attract Muslim tourists.

These problems fall under the macro conditions of globalization, which activate the diverse flows of people, goods and information, and the progress of science and technology to refine certification standards. As further background of these conditions, there are Islamic revival movements in some countries that approve certification and the intensified international competition over initiatives in certification projects. In addition to the factors mentioned above, the problem can also be attributed to a lack of Japanese people's understanding of Muslim diversity in religious practice.

The Koran (the holy book of Islam) requires Muslims to consume halal foods, to what extent, however, a person follows and how he or she practices the teachings of Islam are up to each Muslim (Sai, 2014). Furthermore, the cultural rules or prohibitions regarding food are not exclusive to Muslims; rather, almost all human societies have some cultural restrictions on food. If these are broken, people are subject to social sanctions. In that context, it can be said that food taboos are cultural regulations that make human beings more human (Yamaguchi, 2017). For Muslims, ingesting halal food is surely important, but from the above viewpoint, it is also one of the cultural 
regulations that are widely present in human society. They should not be seen as special or excessively strange.

Because of a lacking of understanding that there is diversity in each Muslim's practice, and that halal certification is not a universal passport to enter the Islamic market, many Japanese companies and municipalities have immediately given up all attempts to accept Muslims once they faced difficulties or could not fulfill the criteria in acquisition of a certification. In other words, they tend to fall into the predicament of "all or nothing." In addition, these companies and municipalities are basically targeting Muslim tourists who return home after consuming items in Japan for a short period of time. There are firms also targeting the Muslim market abroad, but tend to overlook the existence of the local Muslim market in Japan. Various products that gained certification during the boom are often not suited to the tastes of local Muslims and are rarely consumed among them. Some small halal shops run by only a few Muslim and non-Muslims do the bulk of the supplying of halal products to the local Muslims. Such a "face-visible business" shows another feature of halal food businesses in which Muslim customers prioritize the trust in commodities and sellers, rather than halal certification or logos. In that there is a "dualism" between companies and municipalities who are oriented to Muslim tourists and exports, and the retail dealers mainly target local Muslim consumers, some communication and cooperation among them are expected.

The newly produced halal foods in Japan have another significant influence on both producers and consumers, including non-Muslims. According to some producers and sellers of halal products interviewed by the author, the process of obtaining halal certification often provides them the opportunity to review all of their products' materials and manufacturing processes. Though many Japanese people tend to misunderstand that halal foods are only for Muslims, and think non-Muslims are not allowed to consume them, halal foods provided in this way are beginning to be accepted not only by Muslims but also by non-Muslim consumers because their materials and recipes are trustworthy. This kind of safe, secure, and delicious foods can be a common interest and denominator that Muslims and non-Muslims can share. In this way, halal food has the potential to be not only for Muslims but also for non-Muslims.

As the case of Bakery L demonstrated, soon after it dropped its halal certification, some Muslim customers had to give up using the bakery, and the shop closed. This indicates that reducing costs and adjusting the tastes of Japanese consumers to others are certainly big issues if halal businesses want to sustain themselves in Japan. To address these issues, it is essential for us to find out "the third way," apart from obtaining certification to attract Muslims or totally abandoning the acceptance of Muslims without certification. Developing trust might be one of the most important ways to do this. So as to gain the trust of Muslims, it will be crucial to provide consumers with choices of products by disclosing information on their raw materials and manufacturing processes. This is crucial, not only for providing halal foods for Muslims, but also for promoting coexistence between Muslims and non-Muslims. Thinking about halal foods, furthermore, leads us to realize a society that encompasses people who have differences in religion, faith, ways of living, those with or without sicknesses or handicaps, and so on, and helps us to live together in trust. 


\section{References}

Arata, M., 2015. Halal and Booming of Halal Business (Book for Understanding Religion and Modern Times) ed. N Watanabe (Tokyo: Heibonsha) pp. 192-

Arata, M., 2018. Introduction to Halal of food: responding to Muslims that can be done from today (Tokyo: Kodansha)

Higuchi, N. and Tanno, K., 2000 Cross border of Food Culture and Formation of the Halal Food Industry: Cases of Muslim Immigrants in Japan (Social Sciences Research, The University of Tokushima, Vol. 13, pp 99-131

Immigration Bureau Japan official website (http://www.stat.go.jp/data/index.html, downloaded 20 March 2018)

Jetro (Japan External Trade Organization), ed., 2014. Jetro Sensor 64(10) (Tokyo: Japan External Trade Organization)

Okayama Prefecture official website (http://www.pref.okayama.jp/, downloaded 20 March 2018)

Pew Research Centre, 2017. Why Muslims are the world's fastest-growing religious Group (6 April 2017,http://www.pewresearch.org/fact-tank/2017/04/06/whymuslims-are-the-worlds-fastest-growing-religious-group/)

Sai, Y. ed., 2014. Halal of Food (Research Paper Series, Institute for Asian Muslim Studies Center in Waseda University, Vol. 3, Tokyo: Organization for University Research Initiatives)

Tanada, H., 2015. Mosques in Japan, social activities of Muslims in Japan (Yamakawa Shuppannsha)

The Japan Tourism Advisory Council, ed., 2014. Action program to realize a country built on tourism: toward the era of 20 million foreigners visiting Japan (http://www.mlit.go.jp/common/001046636.pdf, downloaded on 20 June 2016)

Tomizawa, H., 2007. Globalization or counter globalization?: the launch of the modern Halal industry centered on Southeast Asia and its significance (Anthropology of Resource, Vol. 4 Lively Small Product) ed. Ogawa, R. (Tokyo: Kobundo), pp. 31748

Yamaguchi, H., 2009. Foodscape of Muslims in local society: production and distribution of Halal food in Okayama prefecture (Indonesian Society in Japan: Issues of International Migration and Symbiosis) M. Okushima ed., (Tokyo: Akashishoten), pp. 233-9

Yamaguchi, H., 2017. Globalization, modernization, and dualism of Halal business: a case from region with less Muslim residents in Japan (To Eat Culture, To Drink Culture: Food and Business in the World under Globalization) ed. M. Arata (Tokyo: Domes Shuppan), pp. 17-45 